Asian Pacific Journal of Reproduction

Journal homepage: www.apjr.net

\title{
Impact of silymarin enriched semen extender on bull sperm preservability
}

\author{
El-Sheshtawy RI ${ }^{凶}$, El-Nattat WS \\ Animal Reproduction and AI Dept., Veterinary Research Division, National Research Centre, Dokki, Egypt
}

\section{ARTICLE INFO}

Article history:

Received 10 December 2016

Revision 16 December 2016

Accepted 2 February 2017

Available online 1 March 2017

\section{Keywords:}

Cattle

Semen

Preservation

Silymarin

\begin{abstract}
Objective: To explore the effect of silymarin on bull spermatozoa during cooling and cryopreservation. Methods: Pooled bull semen were diluted by Tris-Citrate-Fructose egg yolk diluents, purified silymarin powder (obtained from the milk thistle silybum marianum), purchased from Unipharma, Al Obour city, Egypt, was soaked in Tris-citric acid-fructose diluent for $48 \mathrm{~h}$ at $10{ }^{\circ} \mathrm{C}$ making a stock solution $(70 \mathrm{mg} /$ $\mathrm{mL}$ ), from this stock solution we obtained concentrations of $0.18 \mathrm{mg} / \mathrm{mL}, 0.36 \mathrm{mg} / \mathrm{mL}, 0.54 \mathrm{mg} / \mathrm{mL}, 0.72$ $\mathrm{mg} / \mathrm{mL}, 0.90 \mathrm{mg} / \mathrm{mL}$ in addition to the control $(0.00 \mathrm{mg} / \mathrm{mL})$ reaching a final volume of $5 \mathrm{~mL}$ in each tube. Egg yolk was added to each tube to obtain silymarin enriched semen extender (SEE) with $20 \%$ egg yolk, cooled slowly up to $5{ }^{\circ} \mathrm{C}$ and equilibrated for $4 \mathrm{~h}$. Semen was packed into $0.25 \mathrm{~mL}$ polyvinyl French straws (IMV, France). After equilibration periods, the straws were placed horizontally on a rack and frozen in a vapor $4 \mathrm{~cm}$ above liquid nitrogen for $10 \mathrm{~min}$ and were then dipped in liquid nitrogen. Extended semen was subjected to evaluation (motility, alive\%, abnormality\%, intact sperm membrane (HOST)\% and conception rate) in both chilled and frozen semen. Results: Table 1 revealed that Sperm motility of the concentrations 2,3 and 4 after $8 \mathrm{~d}$ of chilling were significantly $(P<0.02)$ higher than control. Sperm motility of the concentration $2(45.00 \% \pm 2.89 \%)$ after $9 \mathrm{~d}$ of chilling was higher than control and the other concentrations. Addition of SEE in concentration 1 and 2 gave post thawing sperm motility as high as the control (47.50 \pm 2.81 and $45.00 \pm 2.58$, respectively) while other concentration have lower effects on motility as compared to the control. Addition of silymarin improved post thawing alive $\%$ and was significantly higher $(P<0.0001)$ than the control. SEE decreased significantly $(P<0.0001)$ the \% of post thawing abnormal sperm in concentration 3 and $4(11.83 \pm 0.65$ and $16.00 \pm 0.58$, respectively). SEE improved significantly $(P<0.018)$ the $\%$ of post thawing intact spermatozoa membranes $($ HOST $\%)$ in concentrations 2,4 and $5(71.17 \pm 0.83,71.83 \pm 0.91$ and $75.00 \pm 3.42$, respectively) (Table 2). Conclusion: It could be concluded that silymarin as a natural additive to semen extenders improved preservability in both chilled and frozen bull semen.
\end{abstract}

\section{Introduction}

Spermatozoa are the end point of male spermatogenesis and have particular anatomic and metabolic features. Nowadays, sperm cryopreservation and storage are of a great demand for conserving the supergenetic origins of the males, the development of artificial reproductive technologies such as artificial insemination (AI) and in vitro fertilization (IVF)[1] are of a great interest. AI with frozen

Corresponding author: Professor Reda, I., El sheshtawy, Animal Reproduction and Artificial Insemination Department, 12622, National Research Centre, Dokki, Giza, Egypt.

Tel: 202-33371635

Fax: 202-37601877

E-mail : rielsheshtawy@gmail.com semen is essential in breeding and selection schedules contributing to increase production of domestic species. Nowadays, semen cryopreservation has many biotechnological applications. It can be used to solve infertility problems, life threatening diseases, preservation of semen and DNA from endangered species and conservation of biodiversity. The interaction of several factors

This is an open access article distributed under the terms of the Creative Commons Attribution-Non Commercial-Share Alike 3.0 License, which allows others to remix, tweak and buid upon the work non-commercially, as long as the author is credited and the new creations are licensed under the identical terms.

For reprints contact: reprints@medknow.com

C2017 Asian Pacific Journal of Reproduction Produced by Wolters Kluwer- Medknow

How to cite this article: El-Sheshtawy RI, El-Nattat WS. Impact of silymarin enriched semen extender on bull sperm preservability. Asian Pac J Reprod 2017; 6(2): $81-84$. 
(cooling rate, storage temperature, chemical ingredients of the extender, cryoprotectant concentration, over accumulation of oxygen free radicals, seminal plasma composition and hygienic control) are the key that affect the life-span of spermatozoa[2]. Cryopreservation of bovine semen often induce an additional source for reactive oxygen species (ROS) attack on sperm due to decreased activities of antioxidant enzymes and the sperm membrane become more susceptible to lipid peroxidation[3] which affect the membrane permeability[4]. Natural antioxidants exert a protective effect preserving the metabolic activity and cellular viability of cryopreserved bovine spermatozoa[5]. Nowadays, the use of herbal natural product has gained interest worldwide. Many of the herbs have been developed into herbal supplement which are claimed to assist in healthy life style. Among these herbs Silymarin is an extract from the seeds and fruits of the milk thistle silybum marianum that contains the flavonolignans silybin which is the major active component. Silymarin is a strong antioxidant used as a remedy for liver protection against oxidative stress and also as a protectant for the testicular tissue and improving semen quality through elevation of blood testosterone level[6,7]. Also, it prevents acetaminophen induced liver injury through restoration of glutathione level[6]. No available literatures were found for interpreting the benefit for using Silymarin.

\section{Materials and Methods}

\subsection{Preparation of silymarin enriched semen extender (SEE)}

Tris-citric acid-fructose diluent (TCF) was prepared according to Foote et al.[8] purified silymarin powder (obtained from the milk thistle silybum marianum), purchased from Unipharma, Al Obour city, Egypt, was soaked in Tris-citric acid-fructose diluent (TCF), (silymarin: TCF) for $48 \mathrm{~h}$ at $10{ }^{\circ} \mathrm{C}$ making a stock solution $(70 \mathrm{mg} /$ $\mathrm{mL}$ ), from this stock solution we obtained concentrations of 0.18 $\mathrm{mg} / \mathrm{mL}, 0.36 \mathrm{mg} / \mathrm{mL}, 0.54 \mathrm{mg} / \mathrm{mL}, 0.72 \mathrm{mg} / \mathrm{mL}, 0.90 \mathrm{mg} / \mathrm{mL}$ in addition to the control $(0.0 \mathrm{mg} / \mathrm{mL})$ reaching a final volume of $5 \mathrm{~mL}$ in each tube. Egg yolk was added to each tube to obtain SEE with $20 \%$ egg yolk (SEEY).

\subsection{Semen collection and initial evaluation}

Three mature cattle bulls maintained at Semen Freezing Center, General Organization for Veterinary Services Ministry of Agriculture, Abbasia, Egypt, were used as semen donors. Ejaculates were collected using a bovine adapted artificial vagina at weekly intervals for $18 \mathrm{wk}$. Semen samples were initially evaluated for subjective sperm motility and sperm concentration. Ejaculates fulfilling minimum standard of sperm motility (70\%) and sperm morphology were pooled in order to have sufficient semen for a replicate and to eliminate the bull effect. The semen was given a holding time for $10 \mathrm{~min}$ at $37^{\circ} \mathrm{C}$ in the water bath before dilution.

\subsection{Semen processing}

Semen samples were diluted with TCF extender and used as control and other aliquots of pooled semen samples were diluted with TCF extenders containing the different concentrations of silymarin in order to provide concentration of 120 million sperm/ $\mathrm{mL}$. Extended semen was slowly cooled (approximately for $2 \mathrm{~h}$ ) to $5{ }^{\circ} \mathrm{C}$ and equilibrated for $2 \mathrm{~h}$. Semen was packed into $0.25 \mathrm{~mL}$ polyvinyl French straws. After equilibrium periods, the straws were horizontally placed on a rack and frozen in vapor $4 \mathrm{~cm}$ above liquid nitrogen for $10 \mathrm{~min}$ and were then dipped in liquid nitrogen. A fraction of extended semen from control and each concentration of the additive were kept at $5{ }^{\circ} \mathrm{C}$ for $7-10 \mathrm{~d}$ (chilling) and sperm motility was evaluated daily.

\subsection{Assessment of semen quality parameters}

The assessment was undertaken on after freeze thawing of bull spermatozoa. Also, sperm motility was evaluated for raw semen, $2 \mathrm{~h}$ after cooling and chilled semen daily up to 7-10 d. Frozen straws were thawed at $37^{\circ} \mathrm{C} / 1 \mathrm{~min}$. The parameters studied were subjective semen characteristics (motility, alive, abnormality and hypoosmotic swelling test (HOST) \%)[9].

\subsection{Statistical analysis}

Statistical analysis data were analyzed using the SPSS (2005)[10] computerized program v. 14.0 to calculate the analysis of variance (ANOVA) for the different parameters between control and additives replications. Significant difference between means was calculated using Duncan test at $P<0.05$.

\section{Results}

\subsection{Effect of SEE on cattle bull sperm motility during chilling}

Sperm motility of the concentrations 2,3 and 4 after $8 d$ of chilling 
Table 1

Effect of silymarin enriched extender on cattle bull sperm motility during chilling.

\begin{tabular}{|c|c|c|c|c|c|c|c|c|c|c|c|}
\hline \multirow{2}{*}{$\begin{array}{c}\text { Treatment } \\
\text { index }\end{array}$} & \multirow{2}{*}{$2 \mathrm{~h}$} & \multicolumn{10}{|c|}{ Days } \\
\hline & & 1 & 2 & 3 & 4 & 5 & 6 & 7 & 8 & 9 & 10 \\
\hline Control & $90.00 \pm 0.00^{\mathrm{a}}$ & $88.33 \pm 1.67^{\mathrm{a}}$ & $88.33 \pm 1.67^{\mathrm{a}}$ & $86.67 \pm 3.33^{\mathrm{a}}$ & $68.33 \pm 1.67^{\mathrm{a}}$ & $60.00 \pm 0.00^{\mathrm{c}}$ & $40.00 \pm 0.00^{\mathrm{d}}$ & $40.00 \pm 0.00^{\mathrm{a}}$ & $36.67 \pm 3.33^{\mathrm{bc}}$ & $25.00 \pm 2.89^{\mathrm{a}}$ & $0.00 \pm 0.00^{\mathrm{a}}$ \\
\hline $\begin{array}{l}1(0.18 \mathrm{mg} / \\
\mathrm{mL})\end{array}$ & $90.00 \pm 0.00^{\mathrm{a}}$ & $90.00 \pm 0.00^{\mathrm{a}}$ & $88.33 \pm 1.67^{\mathrm{a}}$ & $86.67 \pm 3.33^{\mathrm{a}}$ & $76.67 \pm 3.33^{\mathrm{a}}$ & $76.67 \pm 1.67^{\mathrm{a}}$ & $46.67 \pm 4.41^{\mathrm{cd}}$ & $40.00 \pm 0.00^{\mathrm{a}}$ & $40.00 \pm 0.00^{\mathrm{bc}}$ & $36.67 \pm 1.67^{\mathrm{a}}$ & $6.67 \pm 6.67^{\mathrm{a}}$ \\
\hline $\begin{array}{l}2(0.36 \mathrm{mg} / \\
\mathrm{mL})\end{array}$ & $90.00 \pm 0.00^{\mathrm{a}}$ & $90.00 \pm 0.00^{\mathrm{a}}$ & $88.33 \pm 1.67^{\mathrm{a}}$ & $83.33 \pm 1.67^{\mathrm{a}}$ & $76.67 \pm 3.33^{\mathrm{a}}$ & $76.67 \pm 1.67^{\mathrm{a}}$ & $71.67 \pm 1.67^{\mathrm{a}}$ & $58.33 \pm 4.41^{\mathrm{a}}$ & $60.00 \pm 0.00^{\mathrm{a}}$ & $45.00 \pm 2.89^{\mathrm{a}}$ & $0.00 \pm 0.00^{\mathrm{a}}$ \\
\hline $\begin{array}{l}3(0.54 \\
\mathrm{mg} / \mathrm{mL})\end{array}$ & $86.67 \pm 3.33^{\mathrm{a}}$ & $88.33 \pm 1.67^{\mathrm{a}}$ & $86.67 \pm 1.67^{\mathrm{a}}$ & $80.00 \pm 5.00^{\mathrm{a}}$ & $75.00 \pm 2.89^{a}$ & $73.33 \pm 1.67^{\mathrm{ab}}$ & $70.00 \pm 0.00^{\mathrm{a}}$ & $51.67 \pm 10.93^{\mathrm{a}}$ & $53.33 \pm 6.67^{\mathrm{ab}}$ & $33.33 \pm 8.82^{\mathrm{a}}$ & $6.67 \pm 6.67^{\mathrm{a}}$ \\
\hline $\begin{array}{l}4(0.72 \\
\mathrm{mg} / \mathrm{mL})\end{array}$ & $85.00 \pm 2.89^{\mathrm{a}}$ & $86.67 \pm 1.67^{\mathrm{ab}}$ & $86.67 \pm 1.67^{\mathrm{a}}$ & $73.33 \pm 3.33^{\mathrm{a}}$ & $71.67 \pm 1.67^{\mathrm{a}}$ & $65.00 \pm 5.00^{\mathrm{bc}}$ & $63.33 \pm 3.33^{b}$ & $55.00 \pm 7.64^{\mathrm{a}}$ & $51.67 \pm 8.33^{\mathrm{ab}}$ & $36.67 \pm 6.01^{\mathrm{a}}$ & $0.00 \pm 0.00^{\mathrm{a}}$ \\
\hline $\begin{array}{l}5(0.90 \\
\mathrm{mg} / \mathrm{mL})\end{array}$ & $86.67 \pm 1.67^{\mathrm{a}}$ & $83.33 \pm 1.67^{b}$ & $76.67 \pm 1.67^{b}$ & $73.33 \pm 3.33^{\mathrm{a}}$ & $73.33 \pm 3.33^{\mathrm{a}}$ & $63.33 \pm 3.33^{\mathrm{c}}$ & $53.33 \pm 3.33^{\mathrm{c}}$ & $46.67 \pm 3.33^{\mathrm{a}}$ & $33.33 \pm 6.67^{\mathrm{c}}$ & $25.00 \pm 12.58^{\mathrm{a}}$ & $6.67 \pm 6.67^{\mathrm{a}}$ \\
\hline$F$-value & 1.33 & 3.40 & 7.50 & 2.25 & 1.33 & 7.16 & 48.64 & 1.15 & 4.00 & 1.22 & 0.60 \\
\hline
\end{tabular}

Different letter superscripts indicate the significant differences between means within column using the multiple range Duncan's test at $P<0.05$.

were significantly $(P<0.02)$ higher than control. Sperm motility of the concentration $2(45.00 \% \pm 2.89 \%)$ after $9 \mathrm{~d}$ of chilling was higher than control and the other concentrations (Table 1).

\subsection{Effect of SEE on cattle post thawing sperm characteristics}

Addition of SEE in concentration 1 and 2 gave post thawing sperm motility as high as the control $(47.50 \pm 2.81$ and $45.00 \pm 2.58$, respectively) while other concentration have lower effects on motility as compared to the control.

Addition of silymarin improved post thawing alive \% and was significantly higher $(P<0.0001)$ than the control. SEE decreased significantly $(P<0.0001)$ the $\%$ of post thawing abnormal sperm in concentration 3 and $4(11.83 \pm 0.65$ and $16.00 \pm 0.58$, respectively). SEE improved significantly $(P<0.018)$ the $\%$ of post thawing intact spermatozoa membranes (HOST\%) in concentrations 2, 4 and 5 $(71.17 \pm 0.83,71.83 \pm 0.91$ and $75.00 \pm 3.42$, respectively) (Table 2 ).

Table 2

Effect of silymarin enriched extender on cattle post thawing sperm characteristics.

\begin{tabular}{lllcl}
\hline $\begin{array}{l}\text { Treatment } \\
\text { Parameters }\end{array}$ & Motility\% & Alive\% & Abnormal\% & HOST\% \\
\hline Control & $45.83 \pm 3.52^{\mathrm{a}}$ & $61.17 \pm 0.98^{\mathrm{d}}$ & $18.67 \pm 0.33^{\mathrm{bc}}$ & $69.50 \pm 1.61^{\mathrm{ab}}$ \\
$1(0.18 \mathrm{mg} / \mathrm{ml})$ & $47.50 \pm 2.81^{\mathrm{a}}$ & $83.83 \pm 0.95^{\mathrm{a}}$ & $18.67 \pm 0.67^{\mathrm{bc}}$ & $70.00 \pm 1.83^{\mathrm{ab}}$ \\
$2(0.36 \mathrm{mg} / \mathrm{ml})$ & $45.00 \pm 2.58^{\mathrm{a}}$ & $72.83 \pm 1.14^{\mathrm{c}}$ & $18.83 \pm 1.30^{\mathrm{b}}$ & $71.17 \pm 0.83^{\mathrm{a}}$ \\
$3(0.54 \mathrm{mg} / \mathrm{ml})$ & $31.67 \pm 4.01^{\mathrm{b}}$ & $72.83 \pm 1.01^{\mathrm{c}}$ & $11.83 \pm 0.65^{\mathrm{d}}$ & $64.83 \pm 1.17^{\mathrm{b}}$ \\
$4(0.72 \mathrm{mg} / \mathrm{ml})$ & $25.00 \pm 3.42^{\mathrm{b}}$ & $78.33 \pm 1.67^{\mathrm{b}}$ & $16.00 \pm 0.58^{\mathrm{c}}$ & $71.83 \pm 0.91^{\mathrm{a}}$ \\
$5(0.90 \mathrm{mg} / \mathrm{ml})$ & $25.00 \pm 2.24^{\mathrm{b}}$ & $69.83 \pm 0.83^{\mathrm{c}}$ & $22.00 \pm 1.29^{\mathrm{a}}$ & $75.00 \pm 3.42^{\mathrm{a}}$ \\
$F$-value & 11.41 & 46.40 & 15.12 & 3.27 \\
$P<$ & 0.0001 & 0.0001 & 0.0001 & 0.0179 \\
\hline
\end{tabular}

Different letter superscripts indicate the significant differences between means within column using the multiple range Duncan's test at $P<0.05$.

\section{Discussion}

Cryopreservation of sperm is of a great demand[1]. According to Gadea et al.[11], Uysal and Bucak[12] and Bucak et al.[13], minimizing the physical and chemical stresses of cooling, freezing and thawing of sperm cells and consequently improving viability and subsequent fertilizing capacity is achieved by including cryoprotectants in the semen extender. Cryopreservation causes wide-ranging physical, chemical and mechanical injures to sperm membranes of all mammalian species[14], which are attributed to temperature changes, alterations in the transition from the lipid phase, production of reactive oxygen species (ROS) and osmotic stress[5,15]. Moreover, the over accumulation of ROS causes a state of oxidative stress that involves structural damage of sperm membranes, fall of intracellular ATP levels causing decreasing in the viability and motility of cryopreserved sperm[16,17]. To decrease the harmful effects of ROS, seminal plasma possesses powerful source of ROS scavengers which offer protection for sperm, including enzymes such as superoxide dismutase, catalase, glutathione peroxidase, and small molecular antioxidants such as ascorbic acid and a-tocopherol[18,19]. The herbal remedies contain antioxidants to counteract the deleterious action of reactive oxygen species (ROS). Sperm motility was kept high in chilled semen at the concentrations of silymarin $0.36,0.54$ and 0.72 $\mathrm{mg} / \mathrm{mL}$ up to $8 \mathrm{~d}$ of chilling. This indicates that chilled extended semen with these concentrations could be used in AI up to $8 \mathrm{~d}$. Sperm motility of the concentration $0.54 \mathrm{mg} / \mathrm{mL}$ was kept high up to $9 \mathrm{~d}$ of chilling. This means that semen extended with this concentration could be used in AI up to $9 \mathrm{~d}$ of chilling. Addition of silymarin improved post thawing alive $\%$, sperm abnormalities, percent of post- 
thawing intact spermatozoa membranes and maintained the percent of sperm motility. The improved semen quality in both chilled and frozen semen is due to the strong antioxidant capacity of silymarin $[6,7]$. Wellington and Jarvis[20] postulated that the mechanism of action of silymarin is through the stimulation of ribosomal RNA protecting the cell membrane from oxidative damage. They stated also that silymarin stimulates the activity of the antioxidant enzymes superoxide dismutase (SOD) and glutathione peroxidase. It could be concluded that silymarin as a natural additive to semen extenders improved preservability in both chilled and frozen bull semen.

\section{Conflict of interest statement}

The authors declare that they have no conflict of interest.

\section{References}

[1] Medeiros CM, Forell F, Oliveira AT, Rodrigues JL. Current status of sperm cryopreservation: Why isn't better. Theriogenology 2002; 57(1): $327-344$

[2] Barbas JP, Mascarenhas RD. Cryopreservation of domestic animal sperm cells. Cell Tissue Bank 2009; 10(1): 49-62.

[3] El-Sisy GA, El-Nattat WS, El-Sheshtawy RI. Buffalo semen quality, antioxidants and peroxidation during chilling and cryopreservation. Onl J Vet Res 2007; 11: 55-61.

[4] Awda BJ, Mackenzie-Bell M, Buhr MM. Reactive oxygen species and boar sperm function. Biol Reprod 2009; 81(3): 553-561.

[5] Câmara DR, Mello-Pinto MMC, Pinto IC, Brasil OO, Nunes JF, Guerr MMP. Effects of reduced glutathione and catalase on the kinematics and membrane functionality of sperm during liquid storage of ram semen. Small Ruminant Res 2011; 100: 44-49.

[6] Fakurazi S, Nanthini U, Hairuszah I. Hepatoprotective and antioxidant action of Moringa oleifera Lam. againsts acetaminophen induced hepatoxicity in rats. Int J Pharm 2008; 4(4): 270-275.

[7] Luangpirom A, Junaimuang T, Kourchampa W, Somsapt P, Sritragool O. Protective effect of pomegranate (Punica granatum Linn.) juice against hepatotoxicity and testicular toxicity induced by ethanol in mice. Anim
Biol Anim Husb Int J Bioflux Soc 2013; 5(1): 87-93.

[8] Foote RH, Brockett CC, Kaproth MT. Motility and fertility of bull sperm in whole milk extender containing antioxidants. Anim Reprod Sci 2002; 71: 13-23.

[9] Salisbury GW, VanDemark NL, Lodge JR. Semen evaluation: In "Physiology of reproduction and artificial insemination of cattle." 2nd ed. USA: W.H. Freeman \& Compagny, Sanfrancisco; 1978, p. 400-427.

[10]SPSS. SPSS v.14.0 for Windows Evaluation Version Release 2005; 14.0.0.

[11]Gadea J, Gumbo D, Novass C, Zquezf AZ, Grullol A, Gardo GC. Supplementation of the dilution medium after thawing with reduced glutathione improves function and the in vitro fertilizing ability of frozenthawed bull spermatozoa. Andrology 2007; 7: 1-10.

[12]Uysal O, Bucak MN. Effects of oxidized glutathione, bovine serum albumin, cysteine and lycopene on the quality of frozen-thawed ram semen. Acta Vet Brno 2007; 76: 383-390.

[13]Bucak MN, Atessahin A, Yuce A. Effect of anti-oxidants and oxidative stress parameters on ram semen after the freeze-thawing process. Small Rum Res 2008; 75: 128-134.

[14]El-Sheshtawy RI, El-Nattat WS, Sabra HA, Ali AH. Effect of honey solution on semen preservability of local breeds of cattle bulls. World Applied Sci J 2014; 32(10): 2076-2078.

[15]Ortega Ferrusola C, González Fernández L, Morrell JM, Salazar Sandoval C, Macías García B, Rodríguez-Martinez H, et al. Lipid peroxidation, assessed with BODIPY-C11, increases after cryopreservation of stallion spermatozoa, is stallion dependent and is related to apoptotic-like changes. Reproduction 2009; 138(1): 55-63.

[16]Baumber J, Ball BA, Gravence CG, Medina V, Davies-Morel MC. The effect of reactive oxygen species on equine sperm motility, viability, acrosomal integrity, mitochondrial membrane potential, and membrane lipid peroxidation. J Androl 2000; 21(6): 895-902.

[17]Agarwal A, Prahakaran SA, Said TM. Prevention of oxidative stress injury to sperm. $J$ Androl 2005; 26: 653-660.

[18]Aitken RJ, Baker MA. Oxidative stress and male reproductive biology. Reprod Fertil Dev 2004; 16(5): 581-588.

[19]Sikka SC. Role of oxidative stress and antioxidants in andrology and assisted reproductive technology. J Androl 2004; 25(1): 5-18.

[20]Wellington K, Jarvis B. Silymarin: A review of its clinical properties in the management of hepatic disorders. Bio Drugs 2001; 15(7): 465-489. 